\title{
MIR196A1 Pre-miRNA
}

National Cancer Institute

\section{Source}

National Cancer Institute. MIR196A1 Pre-miRNA. NCI Thesaurus. Code C82792.

MIR196A1 is an oligoribonucleotide that is encoded by the human MIR196A1 gene and has a role in the regulation of gene expression. 